\title{
Bitkilerde Programlı Hücre Ölümü
}

\author{
Programmed Cell Death in Plants
}

\author{
Fatma YANIK ${ }^{1}$ (D), Aslıhan ÇETINBAŞ ${ }^{1}$ (D), Filiz VARDAR ${ }^{1}$ (D) \\ Marmara Üniversitesi, Fen Edebiyat Fakültesi, Biyoloji Bölümü, 34722, Göztepe Kampüsü, Kadıköy, İstanbul
}

$\ddot{O} \mathbf{z}$

Programlı hücre ölümü (PHÖ) yaşlanmış, görevini yitirmiş, fazla üretilmiş, düzensiz gelişmiş veya genetik olarak hasarlı hücrelerin, organizma için güvenli bir şekilde yok edilmesini sağlayan, genetik olarak kontrol altında olan bir ölüm mekanizmasıdır. PHÖ vejetatif-generatif organ gelişimi sırasında ve biyotik-abiyotik stres şartları altında bitkilerin farklı organ ve dokularında görülür. Bitkilerde gelişim sırasında hücre ölümü; kök şapkası hücrelerinin değişimi, trakeal elementlerin oluşumu, su bitkilerinde havalandırma parankimasının oluşumu, trikom gelişimi, yaprak senesensi, eşey belirlenmesi ve üreme organlarının gelişimi sırasında ortaya çıar. Bunun yanında virüs, bakteri, mantar gibi biyotik ve UV 1şık, kuraklık, tuzluluk, sıcaklık, donma, sel, ağır metaller, pestisitler gibi birçok abiyotik stres faktörü bitkilerde PHÖ'ye yol açar. Bitkilerdeki PHÖ mekanizması hayvan hücrelerindekine benzer şekilde nukleus morfolojisindeki değişiklikler, kromatin yoğunlaşması, DNA fragmentasyonu, protoplastta büzülme, hücre iskeletinde değişikler ve kaspaz benzeri enzimatik aktiviteler ile gelişir. Apoptotik hücre ölümü görülmeyen bitkilerde, vakuoler ve nekrotik hücre ölümü olmak üzere iki tip ölüm vardır.

Anahtar Kelimeler: Nekrotik hücre ölümü, programlı hücre ölümü, reaktif oksijen türleri, vakuoler hücre ölümü

\begin{abstract}
Cell death which is one of the basic characteristics of both prokaryotic and eukaryotic cells is encountered within the whole organism. Programmed cell death (PCD) is a genetically controlled mechanism, allows retired, dysfunctional, overproduced, irregularly developed or genetically damaged cells to be destroyed safely for organism. It has been first used in 1964 by Lockshin and Williams. Animal apoptosis which is best characterized form of PCD is used first in 1972 by Kerr et al. According to the recent biochemical and molecular studies PCD is categorized in three basic groups: apoptosis, autophagy and necrosis. Plants do not undergo apoptotic cell death, and cell death is classified into two groups as vacuolar and necrotic cell death. In vacuolar cell death, alterations in nucleus morphology, chromatin condensation, DNA fragmentation, protoplast condensation, vacuolization, generation of reactive oxygen species, alterations in the cytoskeleton and caspase like enzymatic activities are observed, as in animal cells. Necrotic cell death has different features from vacuolar cell death such as ATP depletion, cell and mitochondria swelling. PCD appears in different organs and tissues of plants during vegetative-generative organ development and under biotic-abiotic stress conditions. It occurs during the development of plants such as regeneration of root cap cells, formation of tracheal elements, formation of aerenchyma in hydrophytes, trichome development, leaf senescence, sex determination and male-female organ development. Biotic stress factors such as virus, bacteria, fungus and abiotic stress factors such as UV light, drought, salinity, temperature, freezing, flood, heavy metals, pesticides lead to PCD. Under biotic and abiotic stress factors, the balance between antioxidant enzymes and generation of reactive oxygen species (ROS) changes. ROS are free radicals and cause lipid peroxidation, protein oxidation, nucleic acid damage and enzyme inhibition. These alterations in the cellular structures lead to oxidative stress. ROS accumulation also causes caspase-like activities by activating vacuolar processing enzymes, metacaspases, saspases and phytaspases. These proteolytic enzymes execute cell death and cut their substrates from specific amino acid residues such as aspartic acid. PCD can be visualized by light, fluorescence and electron microscopy. Besides DNA fragmentation during cell death is determined by TUNEL, comet assay and gel electrophoresis. Moreover, cytoplasmic cytochrome c identification, caspase like activities and alterations of mitochondrial membrane potential can be identified by biochemical analyses. Although a lot of morphological characteristic features are identified, plant cell death is still not clear with regard to molecular aspects. Molecular characterization of PCD will lead in the future to a better understanding of the mechanisms of plant development and stress tolerance for developing high quality plants.
\end{abstract}

Keywords: Necrotic cell death, programmed cell death, reactive oxygen species, vacuolar cell death 


\section{GİRIŞ}

Prokaryotik ve ökaryotik canlıların temel karakterlerinden birisi olan ölüm, gerek hücre gerekse organizma düzeyinde sıklıkla karşılaşılan bir olaydır. Hücre ölümü ve hücre bölünmesi çok hücreli canlıların dokularında bir denge halindedir. İnsanlarda hücre bölünmesi ve ölümü arasındaki dengenin bozulmastyla ortaya kanser, tip II diyabet gibi birçok sistemik hastalık çıkar. Çok hücreli ökaryotlarda, genetik bakımdan düzenlenmiş olan hücre ölümü normal gelişim ve büyüme için gereklidir. İlk kez 1964 yılında Lockshin ve Williams tarafindan kullanılan programlı hücre ölümü (PHÖ) terimi, klonal bakteriler ve ökaryotik canlıların normal gelişim sürecinde veya biyotik-abiyotik strese karşı hücresel bir cevabın oluşturulması sırasında ortaya çıkan genetik olarak kontrol altında olan fizyolojik bir süreç olarak tanımlanmaktadır [1]. Diğer bir şekliyle yaşlanmış, görevini yitirmiş, fazla üretilmiş, düzensiz gelişmiş veya genetik olarak hasarlı hücrelerin, organizma için güvenli bir şekilde yok edilmelerini sağlayan kontrollü bir ölüm mekanizmasıdır [2, 3]. Hayvan hücrelerinde PHÖ'nün en iyi karakterize olmuş formu olan apoptoz (Yun: ayrılarak düşmek) terimi ise ilk kez 1972 yılında Kerr ve arkadaşları tarafindan bölgesel anemiye maruz kalan karaciğer dokusunun etrafında nekrozdan daha farklı özellikler gösteren hücre ölümü için kullanılmıştır [4]. Yakın zamana kadar hücre ölümü, genetik olarak programlı hücre ölümü olan apoptoz ve ani olarak ortaya çıkan programsız hücre ölümü nekroz olarak iki grupta inceleniyordu. Ancak son yıllarda yapılan biyokimyasal ve moleküler çalışmalar sonucunda PHÖ apoptoz, otofaji ve nekroz olarak 3 temel grupta sınıflandırılmıştır (Tablo 1) [5, 6].

Apoptoza uğrayan hücreler karakteristik olarak hacim kaybederek küçülürler. Bunun yanında hücrede sitoplazma ve kromatin yoğunlaşması, 180-200 bç'lik DNA fragmentasyonu, sitosolik $\mathrm{Ca}^{+2}$ artışı, fosfatidilserinin hücre zarının dışına göçü, sitoplazma ve nukleus parçaları bulunduran zarla çevrili apoptotik cisimlerin oluşması gibi morfolojik ve biyokimyasal değişiklikler gözlemlenir. Hayvanlarda apoptoza uğrayan hücrelerden meydana gelen bu apoptotik cisimler komşu hücreler veya makrofajlar tarafindan fagosite edilirler [7, 8]. Apoptoz, hedef substratların aspartik asit aminoasidinden sonraki peptit bağını kıran ve kaspazlar (caspases-cysteine aspartic proteinases) olarak bilinen sistein proteinazlar familyasına ait düzenleyici proteinler tarafindan başlatılır ve ilerler [9]. Kaspazlar hücreye apoptotik sinyal gelene kadar, hücre içerisinde inaktif prokaspazlar olarak bulunurlar. Bir kez aktive olan kaspaz geri dönüşümsüz olarak çalışmaya başlar ve diğer kaspazları da aktive eder. Kaspaz enzimlerinin yanı sira antiapoptotik ve proapoptotik proteinlerden oluşan Bcl-2 gen ailesi de (bcl-2, bcl-xL, bax, bak, bad vb.) apoptozda ölüm mekanizmasının düzenlenmesinde önemli rollere sahiptir $[10,11]$.
Otofaji (Yun: kendini yeme) evrimsel olarak oldukça korunmuş katabolik bir işlemdir. Otofagozom adını alan sitoplazmanın bir kısmını ve/veya organelleri içeren çift katlı ya da daha fazla zarlara sahip veziküller ile morfolojik olarak karakterize edilirler. Bu tip hücre ölümünde otofagozomlar, asidik hidrolazları içeren lizozomlar veya vakuoller ile birleşerek hücrenin kendi kendini sindirmesine neden olur [12]. Otofajik hücre ölümü, otofaji ile ilişkili genler (autophagy related genes - ATGs) tarafindan düzenlenir. Bu tip ölümde apoptotik kaspazların aktivitesi gözlenmez. Otofaji, özellikle açlık, biyotik-abiyotik stres koşulları altında hücrenin yaşamını devam ettirebilmesi açısından kritik bir rol oynar $[13,14]$. Otofajik hücre ölümü çoğunlukla sitoplazmada zarla çevrili keseciklerle ortaya çıkarken, apoptozun ölüm sırasındaki en önemli hedefi nukleus ve DNA'dır [12].

Nekroz (Yun: doku ölümü) ise apoptoz ve otofajiden oldukça farklı özellikler taşır. Hücre ölümü tipleri ilk tanımlandığında, nekroz programlı olmayan, ani ve patolojik bir ölüm olarak değerlendirilmekteydi [5]. Kendine özgü morfolojik özellikler gösteren nekrozda, hücre hacminin artması, hücresel enerji kaynaklarının azalması, hücre zarı ve organellerde ani bozulmalar görülür. Nekrozun ilerlemesiyle hücrenin bütünlüğü bozularak, bulunduğu dokuda bir inflamasyona (yangı) neden olarak parçalanır. Apoptoz ve otofajiden farklı olarak, bu parçalanmada hücresel içerik tamamen sindirilemez, dokudaki diğer hücreler arasında inflamasyona neden olan hücresel artıklar kalır $[15,16,17]$.

Tablo 1. Apoptoz, otofaji ve nekrozun morfolojik ve biyokimyasal özelliklerine göre karşılaştırılması [18].

\begin{tabular}{|c|c|c|c|}
\hline $\begin{array}{l}\text { Morfolojik-Biyokimyasal } \\
\text { Özellikler }\end{array}$ & Apoptoz & Otofaji & Nekroz \\
\hline DNA fragmentasyonu & + & - & - \\
\hline Kromatin yoğunlaşması & + & - & - \\
\hline Apoptotik cisimler & + & - & - \\
\hline Sitoplazmada vakuolleşme & - & + & + \\
\hline Organel y1kılması & - & + & + \\
\hline Mitokondride şişme & Nadir & $\begin{array}{l}\text { Geç ev- } \\
\text { rede }\end{array}$ & + \\
\hline Sitoplazmik şişme & - & - & + \\
\hline Hücre zarının ani parçalanması & - & - & + \\
\hline ATP tüketimi & + & - & - \\
\hline Kaspaz aktivitesi & + & - & - \\
\hline Doku inflamasyonu (yang1) & - & - & + \\
\hline Hücresel etki & $\begin{array}{l}\text { Tek } \\
\text { hücre }\end{array}$ & $\begin{array}{l}\text { Tek } \\
\text { hücre }\end{array}$ & $\begin{array}{l}\text { Hücre } \\
\text { grubu }\end{array}$ \\
\hline Markır moleküller & $\begin{array}{l}\text { Bcl-2, } \\
\text { Kaspaz- } \\
\text { lar, Bax, } \\
\text { Bad, Bak }\end{array}$ & $\begin{array}{l}\text { LC3, } \\
\text { Beclin-1, } \\
\text { Atg ai- } \\
\text { lesi, } \\
\text { FIP200 }\end{array}$ & $\begin{array}{l}\text { PARP1, } \\
\text { TNF } \alpha, \\
\text { NF-Kß }\end{array}$ \\
\hline
\end{tabular}




\section{BİTKIILERDE PROGRAMLI HÜCRE ÖLÜMÜ}

Prokaryotlar ve ökaryotlar arasında, benzer morfolojik ve biyokimyasal özellikleri olan PHÖ’nün ortak bir atasal hücre ölümü sürecinden evrimleştiği ve ortak bir düzenleyici mekanizmayı paylaştığı düşünülmektedir [19]. Ölen hücrelerin, komşu hücreler tarafından fagosite edilmesini önleyen hücre çeperine sahip olan bitkilerin, bu evrimsel süreçte kendilerine ait bir yol geliştirdikleri sanılmaktadır. Bunun yanında yapılan moleküler analizlerde, hayvanlardaki apoptotik genlerle dizi homolojisine sahip bitki genleri henüz tanımlanamadığı gibi çok az sayıda korunmuş ortak protein bulunmuştur [20].

Bitkilerde hücre ölümünün biyokimyasal ve moleküler mekanizması tam olarak açıklanamamıştır. Bitkilerde hücre ölümü sırasında görülen nukleus morfolojisindeki değişiklikler, kromatin yoğunlaşması, DNA fragmentasyonu, protoplastta büzülme, hücre iskeletinde değişikler ve kaspaz benzeri enzimatik aktiviteler hayvanlardaki apoptoz ile benzer ve ortak morfolojik karakterlerdendir [21]. Ancak bitkilerde meydana gelen PHÖ apoptotik süreç ile gerçekleşmez [21, 22]. Bitkilerdeki PHÖ, vakuoler hücre ölümü ve nekrotik hücre ölümü olarak 2 grupta sinıflandırmaktadır (Tablo 2).

Tablo 2. Bitkilerde vakuoler ve nekrotik hücre ölümünün özellikleri [21].

\begin{tabular}{|c|c|}
\hline $\begin{array}{l}\text { Hücre } \\
\text { Ölümü Tipi }\end{array}$ & Morfolojik ve Biyokimyasal Özellikler \\
\hline \multirow{9}{*}{$\begin{array}{l}\text { Vakuoler } \\
\text { hücre ölümü }\end{array}$} & $\begin{array}{l}\text { Otofagozomların, küçük ve büyük litik vakuolle- } \\
\text { rin oluşumu }\end{array}$ \\
\hline & Sitoiskelet elemanlarının yeniden düzenlenmesi \\
\hline & DNA fragmentasyonu \\
\hline & Kromatin yoğunlaşması \\
\hline & Nukleus zarının bozulması \\
\hline & Vakuoler işlem enzimlerinin (VPE) aktivasyonu \\
\hline & $\begin{array}{l}\text { Tonoplastın parçalanmasına kadar organellerin } \\
\text { bütünlügünün ve turgorun korunması }\end{array}$ \\
\hline & Tonoplastın parçalanması \\
\hline & Hücre içeriğinin tamamen sindirilmesi \\
\hline \multirow{5}{*}{$\begin{array}{l}\text { Nekrotik } \\
\text { hücre ölümü }\end{array}$} & Hücrenin şişmesi \\
\hline & Mitokondrilerde şişme \\
\hline & Hücre solunumu ve ATP üretiminin durması \\
\hline & Plazma zarının erken ve ani parçalanması \\
\hline & $\begin{array}{l}\text { Hücre içeriği sindirilemeden artıklar halinde kal- } \\
\text { ması }\end{array}$ \\
\hline
\end{tabular}

Hayvanlardaki otofajik hücre ölümü ile ortak özellikler taşıyan vakuoler hücre ölümünde, vakuoller büyük önem taşımaktadır. Bilindiği gibi bitki hücrelerinde 2 tip vakuol vardır. Bunlardan biri çeşitli maddelerin biriktiği depo vakuolü, diğeri ise aspartat proteinazlar, sistein proteinazlar ve nükleazlar gibi hidrolitik enzimleri içeren litik vakuollerdir [23]. Bitkilerde hücredeki litik vakuollerin hacminin artması ve en sonunda vakuol zarı olan tonoplastın parçalanarak hidrolitik enzimlerin sitoplazmaya geçmesi ile hücre ölümü gerçekleşir. Tonoplastın parçalanmasına kadar kromatinde yoğunlaşma ve DNA fragmentasyonu gözlemlenirken, henüz bozulmamış mitokondri, plastitler gibi sitoplazmik organeller hücrede varlığını ve aktivitesini korur. Vakuolün parçalanması ile birlikte tüm hücresel yapıların yıkılması gerçekleşir. Bunun yanında nekrotik hücre ölümünde plazma zarı ve organellerin erken ve ani parçalanması gerçekleştiği için vakuoler hücre ölümünden farklı özellikler gösterir. Nekrotik hücre ölümünde hücre ve hücre organelleri şişer, plazma zarı erken bozulma gösterir, mitokondri yapısı bozulduğu için hücre solunumu gerçekleşemez. Bununla birlikte bu tip ölümde hücrede reaktif oksijen türleri (ROT) artar ancak ATP üretimi azalır. Bitkilerde vakuoler hücre ölümü gelişim veya stres koşulları altında gerçekleşen fizyolojik bir olayken, nekrotik hücre ölümü bitkinin karşılaştığ1 ani ve şiddetli stres koşulları altında oluşan patolojik bir ölüm sürecidir [21].

Bitkilerin çeşitli vejetatif ve generatif doku ve organlarının gelişimi ve olgunlaşması sırasında vakuoler hücre ölümü görülür. Bu PHÖ’nün ilgili hücrelerde zamanından önce veya geç görülmesi ya da hiç gerçekleşmemesi doku ve organ gelişiminde yapısal ve fonksiyonel bozukluklara sebep olur. Bunun yanında bitkilerin maruz kaldığı biyotik ve abiyotik stres şartlarında da bitkilerin değişik doku ve organlarında PHÖ görülür.

\subsection{Bitkilerde Gelişim Sırasında Görülen Programlı Hücre Ölümü}

İletim demetli bitkiler embriyogenez, döllenme, doku ve organların normal gelişimleri sırasında PHÖ’ye uğrarlar (Şekil 1). Bitkiyi toprağa bağlayan vejetatif bir organ olan kök toprak içerisinde ilerlerken kök şapkası hücreleri onu mekanik zararlardan korur. Zarar gören veya yaşlanan kök şapkası hücreleri PHÖ’ye uğrayarak hızlı bir değişim sürecinden geçer. Bitkilerde PHÖ sürecinden geçen ksilem elemanlarından trake-trakeitlerin oluşumu Zinnia elegans'ta ayrıntılı bir biçimde incelenmiştir. Z. elegans'ta mezofil hücrelerinin trakeal elementlere değişimi sırasında vakuoler hücre ölümü meydana gelir. Ancak çok hızlı gerçekleşen bu ölüm sürecinde nukleus değişiklikleri ve DNA fragmentasyonu gözlemlenmez. Hücresel içeriğin hızlı bir şekilde sindirilmesinden sonra geriye sekonder çeperlerden oluşan boru şeklinde hücreler kalır. Özellikle su bitkilerinin kök korteks tabakasında çeşitli gazların depo edilebilmesi için büyük boşlukların oluşumu sırasında da parankimatik 
hücreler PHÖ'ye uğrar. Böylece havalandırma parankiması (aerenkima) oluşur. Bunların yanında sklerenkima oluşumu, trikom (tüy) gelişimi, yaprak absisyonu ve senesensi, çiçeklerde dişi veya erkek eşeyin belirlenmesi ve üreme organlarının gelişimi sırasında PHÖ normal bir süreç şeklinde ortaya çıkar [24, 25, 26, 27].

Dişi ve erkek üreme organlarının gelişimi, bitkilerde PHÖ'nün gösterilmesi için zengin bir araştırma alanıdır. Erkek eşey organı gelişimi sırasında anter loblarını bir arada tutan konnektif doku, anter çeper tabakalarından tapetum, endotesyum ve ara tabaka hücreleri, polen tanelerinin tam olarak gelişip doğaya salınması için zamanı geldiğinde hücre ölümüne uğrarlar. Bunun yanında kendine uyuşmaz bitkilerde polenlerin pistil ile etkileşimi sırasında, polen tüpü stilus içinde hücre ölümüne uğrayarak mikropile ulaşamadan körelir. Stilüste polen tüpünün geçişi için kanal yapısı bulunmayan türlerde tüpün ilerlediği yere rastlayan hücrelerde de PHÖ gerçekleşir. Dişi eşey organının gelişiminde ise mayoz sonunda faal olmayan megasporlarda, nusellus dokusunda, embriyo kesesi hücrelerinden sinergit ve antipotlarda, embriyoyu endosperma (besi doku) içine iten suspansör hücrelerinde, apomiktik kese oluşumunda ve tohum çimlenmesi sırasında endospermada PHÖ görülür [26, 28, 29, 30, 31].

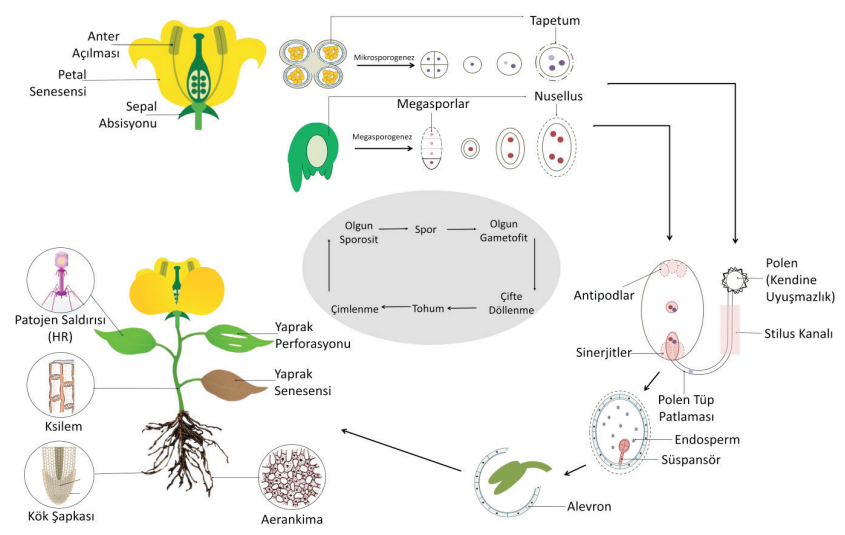

Şekil 1. Bitkilerde gelişim sırasında vejetatif ve generatif organlarda görülen hücre ölümü [30].

Durme ve Nowack [32] bitkilerin gelişimi sırasında görülen hücre ölümünü 3 evreye ayırmıştır. 1. evrede öncelikle sinyal molekülü olan farklı bitki büyüme düzenleyicilerinin tetiklemesi ile hücre ölümünde görevli hidrolitik enzimler litik vakuollerde birikmeye başlar. 2 . evrede $\mathrm{Ca}^{+2}$ ve ROT gibi sekonder sinyal molekülleri hücre içinde ölüm mekanizmasını başlatırlar. Hücre ölümü öncelikle litik vakuoller içerisinde hidrolitik enzimlerin yardımıyla otofajik olarak gerçekleşmeye başlar. Sitosolik pH'nın düşmesi ile birlikte hidrolitik enzimler sitoplazmaya geçmeye başlar. 3. evrede ise tonoplast ve sonrasında plazma zarı parçalanır. Hücrenin geriye kalan tüm bileşenleri sindirilir. Bazı tip hücrelerde (tapetum, megasporlar vb.) hücre ölümü sırasında hücre çeperi de tamamen sindirilirken, bazılarında ise (ksilem elemanları, sklerenkima vb.) sindirilmeden kalır. Her ne kadar bitkilerde gelişim sırasında görülen hücre ölümünün genetik olarak kontrol altında olduğu bilinse de, yaprak gibi bitki organlarının yaşlanarak ölümü olarak tanımlanan senesenste bu genetik kontrol ani mevsimsel değişiklikler gibi çevresel etmenlerden de etkilenmektedir [30, 32].

\subsection{Bitkilerde Stres Sırasında Görülen Programlı Hücre Ölümü}

Bitkilerin bazı doku ve organları biyotik ve abiyotik stres koşulları altında PHÖ'ye uğrarlar [28, 33]. Bitkilerde çok yaygın olarak görülen virüs, bakteri, mantar gibi patojenlerin bitkiye bulaşması sonucunda ortaya çıkan ölüm "Aşırı Duyarlılık Cevabı" (Hypersensitive Response-HR) olarak adlandırılmaktadır [34]. Biyotik stres şartlarında ortaya çıan bu ölüm sırasında, bir patojenin bitki tarafından tanınması ile programlı ölüm mekanizması hızlı bir şekilde devreye girer. Enfekte olan hücreler fenoller gibi çeşitli sekonder metabolitleri üreterek hem kendisinin ölümüne hem de çevresindeki hücreleri uyararak onların ölümüne sebep olur. Böylece patojenin enfekte ettiği hücrenin etrafını çeviren ölü hücrelerden oluşan bir tabaka meydana gelir. HR ile dokuda meydana gelen ölüm, patojenin daha fazla hücreyi etkileyip yayılmasını engellemekte ve bir sinyal oluşturarak bitkinin diğer savunma mekanizmalarını uyarabilmektedir [35]. Her ne kadar HR nekrotik ölüme benzer özellikler gösterse de litik vakuollerin oluşumu, otofajik aktivitenin artması, ROT artışı ve tonoplast parçalanması sonucunda gösterdiği hücresel bozulma özellikleri bakımından vakuoler hücre ölümüyle ortak özellikler göstermektedir. Ancak nekrotik hücre ölümünde olduğu gibi ölüm sonrasında hücresel artıklar tamamen sindirilemeden kalır [21].

Bitkiler biyotik stres faktörlerinin yanında yer değiştirememelerinden dolayı yaşam döngüleri boyunca büyüme ve gelişmelerini olumsuz yönde etkileyecek düzeyde UV ışı, kuraklık, tuzluluk, sıcaklık, donma, sel, ağır metaller, pestisitler, nanopartiküller gibi birçok abiyotik stres faktörü ile de karşılaşırlar. Biyotik stres koşullarında olduğu gibi abiyotik stres koşulları altında da ROT'ların üretimi artmaktadır. Hücresel ROT konsantrasyonunun artması durumunda, antioksidan savunma sistemleri ve ROT üretimi arasındaki denge bozulmakta ve zincirleme reaksiyonlar şeklinde bitkiler oksidatif strese girmektedir. Stres altında ROT üretiminin artışı lipitlerin peroksidasyonuna, proteinlerin 
oksidasyonuna, nükleik asit hasarına, enzim inhibisyonuna neden olur ve bunların sonucunda PHÖ ortaya çıkar [36, 37, 38]. PHÖ stresin bitkiyi etkilemesine bağlı olarak ya bazı doku ve organlarda veya tüm bitkide gözlemlenebilir. Stres koşulları altında bitkilerde gözlemlenen hücre ölümü bitkinin normal gelişimini etkilediği gibi tarımsal açıdan bakıldığında verimi ve ürün eldesini de etkilemektedir. $\mathrm{Bu}$ durumda ekonomik bakımdan zararlara sebep olmaktadır.

\subsection{Reaktif Oksijen Türlerinin Hücre Ölümündeki Rolü}

Reaktif oksijen türleri (ROT) bitkilerde endojen olarak kloroplast, mitokondri ve peroksizomlarda çeşitli enerji dönüşüm reaksiyonları sırasında oluşan serbest radikallerdir [39]. Bitkinin normal gelişim sürecinde de sentezlendikleri halde detoksifikasyon mekanizması ile aralarındaki denge sayesinde zararlı etki oluşturmazlar [40]. ROT'lar diğer moleküllere elektron verebildiklerinden ya da onlardan elektron alabilmelerinden dolayı organizmada indirgeyici veya yükseltgeyici olarak davranırlar [41]. Hücrelerde bilinen başlıca ROT'lar moleküler oksijenin $\left(\mathrm{O}_{2}\right)$ indirgenmiş formlarıdır (Şekil 2). $\mathrm{O}_{2}$ molekülünün elektron alması ile açığa çıkan ve en çok rastlanan ROT'lar singlet oksijen $\left({ }^{1} \mathrm{O}_{2}\right)$, süperoksit radikali $\left(\mathrm{O}_{2}{ }^{-}\right)$, peroksit $\left(\mathrm{O}_{2}{ }^{2-}\right)$, hidrojen peroksit $\left(\mathrm{H}_{2} \mathrm{O}_{2}\right)$ ve hidroksil iyonu $(\mathrm{OH} \cdot)^{\prime}$ 'dur [42].
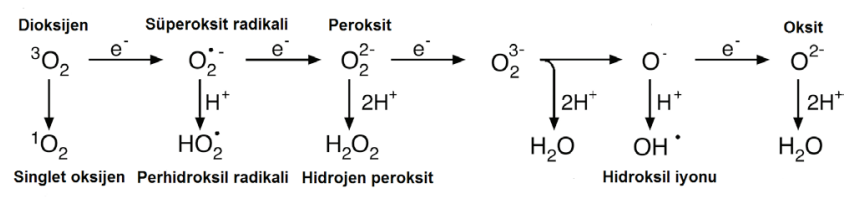

Şekil 2. Moleküler oksijenin indirgenerek ROT'ların oluşumu [43].

Gelişimsel ve çevresel strese karşı toleransı da kapsayan birçok hücresel süreçte ROT'lar düşük konsantrasyonlarda sekonder mesajcılar olarak da rol oynamaktadırlar. Ancak yüksek konsantrasyonda üretilen ROT'lar hücrede zararlı ve zincir etkilere sebep olmaktadır. Hücrede fazla üretilen ROT'ların detoksifikasyonu antioksidan enzimler ve enzimatik olmayan antioksidan sistemleri ile gerçekleştirilir. Süperoksit dismutaz (SOD), katalaz (CAT), askorbat glutatyon (AsA-GSH), askorbat peroksidaz (APX), hidrojen peroksidaz (POD) ve glutatyon redüktaz (GR) ROT'ların detoksifikasyonun rol alan antioksidan enzimlerdir. Askorbat (AsA), glutatyon (GSH), karotenoitler, tokoferoller ve fenolik bileşikler ise enzimatik olmayan antioksidanlar adı altında incelenmektedir [44]. Bitkilerde antioksidan savunma mekanizmasının aktivitesi çeşitli çevresel streslerin uyarmasına bağlı olarak oluşan oksidatif stresin yok edilmesi sırasında artış gösterir. Bitkinin ROT'ları detoksifiye etmek için yüksek antioksidan kapasitesini koruması bitkinin strese olan toleransına bağlıdır. Hücre içerisinde anormal ROT birikiminin en önemli ROT yakalayıcı enzim olan katalazın yıkımina sebep olmaktadır. Bunun yanında ROT birikimi farklı mekanizmalar ile DNA'nın baz ve şekerinde hasar, tek ve çift zincir kırıkları, DNA-protein çapraz bağlanması gibi bir takım modifikasyonlara sebep olur. Bu şekilde hücrede artarak biriken ROT'lar PHÖ sürecinin başlayarak ilerlemesine sebep olur [45, 46].

Bitki gelişimde olduğu gibi abiyotik veya biyotik stres koşullarına maruz kalmış bitkilerde gelişen hücre ölümünün ROT miktarının değişmesi ile kontrol edildiği bilinmektedir [47]. En iyi bilinen gelişimsel hücre ölümü tipi olan organ senesensi ve çimlenme sırasında alevronlarda gerçekleşen hücre ölümünün, ROT ve etilen hormonu işbirliği ile gerçekleştiği bilinmektedir. ROT üretilmesi ve detoksifiye edilmesi arasındaki denge; herbisitler ve patojen saldırılar gibi çeşitli biyotik stresler veya tuzluluk, UV radyasyonu, kuraklık, ağır metaller, aşırı sıcaklık, besin eksikliği ve hava kirliliği gibi çeşitli abiyotik stresler tarafindan bozulur. $\mathrm{Bu}$ dengenin bozulması, hücreler arasındaki ROT miktarının aniden artmasına ve hücre yapisinda oksidatif hasara neden olabilir [48]. PHÖ her türdeki ROT'lar ile başlatılabilir. Hidroksil radikalleri lipid peroksidasyonunu başlatarak hem kendileri hem de bu olay sonucu açığa çıkan diğer ROT'lar ile hücre ölümünü başlatıp devam ettirebilir [39].

Pirinç $d t c 1$ mutantında ROT birikiminin olmaması sebebiyle tapetal PHÖ'nün geciktiği ve steril (kısır) polenlerin geliştiği belirlenmiştir [49]. Arabidopsis'te ise tapetal PHÖ'nün zamanlaması ROT üretimindeki değişmeler sebebiyle gecikmiş ve bunun sonucunda polen tanelerinin gelişimi ve olgunlaşmasında aksamalar meydana gelmiştir [50]. ROT birikiminin PHÖ'de rol oynayan proteazları aktive ettiği bilinmektedir. Bu durumun en iyi örneği haşhaşta kendine uyuşmaz polenlerin polen tüplerinin oluşumu sırasında ve spermin yumurtaya nakli sırasında polen tüplerindeki ROT artışı verilebilir [51, 52]. Gelişim sırasında ROT üretimi ve birikiminin arttığ gibi, stres koşulları altında da ROT ve buna bağlı olarak antioksidan enzim artışı gözlenmektedir. Aluminyum stresine maruz kalan arpa köklerinde ROT artışı, süperoksit dismutaz ve peroksidaz enzim aktivitesi ve bunların sonucu olarak da DNA fragmentasyonu gözlemlenmiştir [53].

\subsection{Bitkilerde Kaspaz Benzeri Aktiviteler}

Hayvan hücrelerinde PHÖ’nün en iyi karakterize olmuş formu olan apoptoz oldukça korunmuş ve kaspazlar olarak 
bilinen sistein proteinaz ailesi tarafından yürütülür. Kaspazlar hedefledikleri substratları P1 pozisyonunda aspartik asit birimlerinden keserler. Kaspazlar hücre içerisinde inaktif zimojenler olarak sentezlenirler ve prokaspaz adını alırlar. $\mathrm{Bu}$ inaktif prokaspaz enzimleri apoptoz sinyalinin alınmasiyla birlikte aktifleşirler ve aktifleşen bu kaspazlar diğer inaktif kaspazları aktive ederler. Memelilerde 13 farklı kaspaz enzimi vardır. Bunlardan kaspaz-2, $-8,-9,-10$ başlatıcı, kaspaz $-3,-6,-7$ infazc1, kaspaz $-1,-4,-5,-11,-12,-14$ ise enflamatuvar kaspazlardır [54] .

Bitkilerde proteoliz hücresel yapılarda birçok enzimi ve çeşitli proteolitik yolları içeren karmaşık bir süreçtir [55]. Bitkilerde gelişme, patojen ve abiyotik stres nedenli hücre ölümü ile ilişkili çok çeşitli proteolitik enzim bilinmektedir. Son yıllardaki çalışmalar hayvanlardaki kaspazlarla yapısal homoloji gösteren sistein proteinaz ve serin proteinazların hücre ölümünde rol aldığını (Tablo 3) ve hayvanlardaki kaspazlara benzer olarak substratlarını aspartik asit, aspargin, arginin veya lizinden sonra kestiğini ortaya koymuştur [54, 56]. Birçok destekleyici çalışma hücre ölümüne uğrayan bitkilerin ekstrelerinin insan kaspaz - 1 substratı YVADAMC ve insan kaspaz - 3 substratı DEVD-AMC gibi sentetik kaspaz substratlarına etki ettiğini göstermiştir. Benzer olarak YVAD-CHO ve DEVD-CHO gibi kaspaz inhibitörlerinin bitki hücre ölümünü birçok sistemde baskıladığı gösterilmiştir [19, 20, 57]. Bu çalışmalar bitkilerde kaspaz benzeri aktivitelerin varlığını kuvvetli bir şekilde ortaya koyar. Çok hücreli organizmalarda muhtemel hücre ölümünün kökeni ve apoptozun bazı özelliklerinin korunmasının kısmen de olsa moleküler seviyede yansıması beklenmektedir. Fakat Arabidopsis genom dizisi tamamlandığı halde sadece çok az bitki geninin memelilerde görülen apoptoz geni ile ortak olduğu görülmüştür. Bitkilerde kesin kaspaz homologları olmadığı halde ölen bitki hücrelerinde proteolitik kaspaz benzeri aktivitenin artması, hayvan kaspazları ile fonksiyonel olarak eş olan özel bitki proteinazlarının bulunduğunu düşündürür $[20,58,59,60]$.

İlk kez 1998'de tütünde bakteriler tarafından oluşturulan PCD'de sentetik kaspaz - 1 substratına karşı proteolitik aktivite gözlemlenmiştir [56]. Bitkilerde vakuollerde bulunan ve kaspaz - 1 substratını katalizleyen bir sistein proteinaz olan vakuoler işlem enziminin (Vacuolar processing enzyme-VPE) gelişim ve stres sırasında hücre ölümünde kritik rol oynadığ 1 belirlenmiştir [61]. Bu bulgularla birlikte kaspaz benzeri aktiviteler çeşitli sentetik kaspaz substratları kullanılarak belirlenmiştir [62, 63]. Bunun yanında son yıllarda protoza, mantar ve bitkilerde ortak olarak bulunan bir sistein proteinaz olan kaspaz ortologları da bulunmuştur. Metakaspazlar hayvansal kaspazlarla yapısal benzerlik gösterse de substratlarını arjinin ve lizin aminoasitlerinden sonra kesmektedirler. Arabidopsis ile yapılan çalışmalarda 9 farklı metakaspazın farklı düzeylerde farklı dokularda sentezlendiği belirlenmiştir [64]. Avena sativa'da (yulaf) patojen saldırısı sonucunda meydana gelen PHÖ’nde kaspaz 6 benzeri aktivite gösteren serin proteinazlara ait fitaspaz ve saspaz aktiviteleri gözlemlenmiştir. Buna ek olarak Arabidopsis thaliana' da $26 \mathrm{~S}$ proteozom $B 1$ alt ünitesinin ksilem gelişiminde ve bakteri enfeksiyonu sırasında kaspaz - 3 substratını katalizleyerek PHÖ’ne aracılık ettiği belirlenmiş$\operatorname{tir}[54]$.

Tablo 3. Bitkilerde programlı hücre ölümü ile ilişkili proteinazlar

\begin{tabular}{llll}
\hline Proteinaz adı & Proteinaz ailesi & Substrat & $\begin{array}{l}\text { Etki ettikleri } \\
\text { kaspaz substratı }\end{array}$ \\
\hline VPE & Sistein proteinaz & $\begin{array}{l}\text { Asparjin } \\
\text { Aspartik asit }\end{array}$ & $\begin{array}{l}\text { YVAD (kaspaz-1 } \\
\text { substratı) }\end{array}$ \\
\hline $\begin{array}{l}\text { 26S proteozom } \\
\text { 1 alt ünitesi }\end{array}$ & Treonin proteinaz & $\begin{array}{l}\text { Glutamik asit } \\
\text { Aspartik asit }\end{array}$ & $\begin{array}{l}\text { DEVD (kaspaz-3 } \\
\text { substratı) }\end{array}$ \\
\hline Saspaz & Serin proteinaz & Aspartik asit & $\begin{array}{l}\text { VKMD (kaspaz-6 } \\
\text { substratı) }\end{array}$ \\
\hline Fitaspaz & Serin proteinaz & Aspartik asit & $\begin{array}{l}\text { IETD (kaspaz-8 } \\
\text { substratı) }\end{array}$ \\
\hline Metakaspaz & Sistein proteinaz & Arjinin, lizin & $\begin{array}{l}\text { VEID (kaspaz-6 } \\
\text { substratı) }\end{array}$ \\
\hline
\end{tabular}

\section{BITKILERDE PROGRAMLI HÜCRE ÖLÜMÜNÜN ANALİZI}

Hayvan hücrelerinde olduğu gibi bitki hücrelerinde de PHÖ süreci birçok yöntem ile baştan sona gözlemlenebilir. PHÖ’nün varlığı temel olarak mikroskobik teknikler kullanılarak belirlenir. Özellikle hematoksilen, toluidin mavisi gibi genel yapı boyalarının kullanılması ile nukleus morfolojisindeki değişiklikler karşılaştırmalı olarak saptanabilir. Nukleus ve kromatin değişiklikleri DAPI (4',6-diamidino-2-phenylindole), Hoechst, propidium iodit gibi nukleus ve kromatine özgü işaretleyiciler yardımıyla floresan mikroskopta da görüntülenebilir. PHÖ ile DNA'da nukleozomlar arası bölgelerde oluşan kırıklar TUNEL (TdT-dUTP nick-end-labelling) yöntemi ile de özgül olarak belirlenebilir. Terminal deoksinükleotidil transferaz (TdT) enzimi ve fluorescein gibi floresan boyalarla işaretli nükleotidler kullanılarak yapılan in situ işaretleme ile 1şıma yapan (PHÖ geçiren) ve 1şıma yapmayan (PHÖ geçirmeyen) hücreler belirlenebilir. Nukleus ve kromatin yapısındaki değişikliklerin yanı sıra PHÖ sırasında hücrenin ince yapısında meydana gelen değişiklikler, elektron mikroskobu kesitleri ile ayrıntılı olarak incelenebilir [65]. Vardar ve Ünal [26] Lathyrus undulatus L. anter çeper tabakalarından tapetumun gelişimini ayrıntılı olarak incelemişlerdir. Tapetumun gelişimi sırasında PHÖ'nün polen taneleri tetrattan salındıktan sonra başladığı toluidin 
mavisi, DAPI ve TUNEL işaretleme yöntemleriyle saptanmıştır. Araştırıcılar ayrıca elektron mikroskobu ile PHÖ sırasında hücrenin ince yapısında meydana gelen değişiklikleri de ayrıntılı olarak belirlemişlerdir. Araştırıcıların elde ettikleri sonuçlara göre, PHÖ vakuolleşme, nukleus ve kromatin değişiklikleri ile başlayıp, tonoplastın parçalanmasıyla birlikte tüm hücresel içeriğin sindirilerek sonlanmaktadır.

Mikroskobik tekniklerin yanı sıra PHÖ'nün belirlenmesi için en sık kullanılan yöntem genomik DNA'da meydana gelen fragmentasyonun belirlenmesidir. Bu amaç için genomik DNA agaroz jel elektroforezinde yürütülür. PHÖ geçirmeyen örneklerde genomik DNA jelde ilerleme göstermezken, DNA'sı fragmente olmuş örneklerde farklı büyüklüklerdeki DNA parçaları jelde farklı hızlarda ilerleyerek merdiven basamağı görüntüsü oluşturur. Jel elektroforezi yöntemi nekroz ve vakuoler hücre ölümünün karşılaştırılmasında da kullanılabilir. Nekrozda ani ve rastgele DNA parçalanması gerçekleştiği için bu parçalar jelde ilerlerken merdiven basamağından çok, yayılmış (smear) bir görüntü verir [65]. Agaroz jel elektroforezi yönteminin yanında PHÖ kaynaklı DNA hasarı komet yöntemiyle de belirlenebilmektedir. Bitkisel materyalden izole edilen nukleuslar etidyum bromür, akridin oranj gibi DNA bağlayıcı floresan boyalarla boyanırlar [16]. Eğer DNA kırık içeriyorsa, gevşemiş ve kırılmış DNA parçaları elektrik yüklü ortamda, nukleustan anoda doğru göç ederek kuyruklu yıldız görünümünü verir. DNA hasarını saptamak için kuyruk uzunluğu ölçülerek hasarın büyüklüğü karşılaştırmalı olarak belirlenir. Kontrol grubundaki nukleuslarda DNA fragmentasyonu olmadığı için kuyruk oluşumu görülmez, küresel şeklini korur [66]. Vardar ve ark. [67] farklı Gramineae türlerinde, abiyotik stres faktörlerinden biri olan alüminyum $(\mathrm{Al})$ toksisitesinin PHÖ'nün hangi saatte başlattığını belirlemek için agaroz jel elektroforezini kullanmışlardır. Elde edilen sonuçlara göre Al toksisitesi tritikale, çavdar, arpa ve yulafta 2 saat içerisinde PHÖ'nün belirteçlerinden biri olan DNA fragmentasyonuna sebep olmuştur. Benzer şekilde Yanık ve Vardar [68] nanopartikül stresine maruz kalmış köklerde zaman ve doza bağımlı olarak DNA fragmentasyonu gözlemlemişlerdir. Bunun yanında tritikale, buğday ve çavdar köklerinde Al toksisitesi 15. dakikadan itibaren komet analizi kullanılarak, uzamış kuyuk oluşumlarının ölçülmesi ile belirlenmiştir [69].

Daha önce de belirtildiği gibi bitkilerde kaspaz benzeri aktiviteler hayvan hücrelerindeki kaspaz substratları ve inhibitörleri kullanılarak spektrofotometrik olarak belirlenebilir. Birçok araştırıcı bitkilerde özellikle abiyotik stres sonucunda oluşan kaspaz benzeri aktiviteyi kaspaz-1 (YVAD), kaspaz-3 (DEVD), kaspaz-8 (IETD) ve kaspaz-9 (LEHD) substratlarını kullanarak kolorimetrik ve florometrik olarak ölçmüşlerdir $[62,63]$. Bunun yanında PHÖ sırasında hem hayvan hem de bitki hücrelerinde ortak olarak gözlemlenen mitokondrilerden sitokrom c salınımı western blotlama (immunoblotlama) yöntemiyle belirlenebilmektedir. $\mathrm{Bu}$ yöntemde hücrelerden izole edilmiş bir protein karışımı içindeki belirli bir proteinin varlığını ve büyüklüğünü saptamak için antikor-antijen özgüllüğü kullanılır. Panda ve ark. [70] Al stresine maruz kalan tütün hücrelerindeki mitokondriyel değişiklikleri izlemişlerdir. Araştırıcılar yaptıkları ayrıntılı çalışmalar sonucunda hücrede ROT'ların artması ile birlikte mitokondri iç zarının potansiyelinde değişiklikler meydana geldiği ve bunun sonucunda da sitokrom c'nin sitoplazmaya salınarak PHÖ’ne sebep olduğunu belirtmişlerdir.

\section{SONUÇ}

PHÖ prokaryotik ve ökaryotik tüm canlılarda gelişimsel ve çevresel sinyallerin tetiklemesi ile başlayan, genetik olarak kontrol altında olan bir süreçtir. Bitkiler de hücre ölümü hayvanlardaki apoptozla ortak morfolojik özelliklere sahiptir. Ancak hayvanlardaki apoptotik genlerle dizi homolojisine sahip bitki genleri ve homolog proteinler henüz tanımlanamamıştır. Morfolojik bakımdan gelişim sırasında görülen hücre ölümünün vakuoler hücre ölümü tipinde, strese bağımlı hücre ölümünün ise hem nekrotik hem de vakuoler hücre ölümü tipinde olduğu belirlenmiştir. Ancak PHÖ'nün başlatılması, devamı ve sonuçlanması sırasında gerçekleşen moleküler olaylar ve transkripsiyon faktörleri henüz aydınlatılamamıştır. Bunun yanında gelişimsel ve stres kaynaklı PHÖ’nün aynı veya farklı mekanizma tarafından $\mathrm{m}$ kontrol edildiği de hala tartışma konusudur [60]. Bitkilerde hücre ölümünü kontrol eden proteinlerin ve genlerin tanımlanarak anlaşılması, özellikle stres koşulları altında gelişen hücre ölümünün engellenmesi ve bitkide strese karşı tolerans mekanizmasının geliştirilmesi açısından önemlidir. Çevresel streslere karşı tolerans geliştirilmesi, gelecekte birçok tarımsal ürünün ıslahı ve veriminin arttırılması bakımından çok önemlidir. Bunun yanında normal gelişim sırasında meydana gelen PHÖ'nün erken gerçekleşmesi, gecikmesi veya hiç olmaması ile gerçekleşen gelişimsel bozuklukların önlenmesinde de yardımcı olacaktır.

\section{KAYNAKLAR}

[1] Lockshin, R.A., Williams, C.M., (1964). Programmed cell death. II. Endocrine potentiation of the breakdown of the intersegmental muscles of silkmoths. Journal of Insect Physiology, 10, 643-649.

[2] Bayles, K.W., (2014). Bacterial programmed cell death: Making sense of a paradox. Nature Reviews Microbiology, 12, 63-69. 
[3] Wang, J., Bayles, K.W., (2013). Programmed cell death in plants: Lessons from bacteria? Trends in Plant Science, 18(3), 133-139.

[4] Kerr, J.F.R., Wyllie, A.H., Currie, A.R., (1972). Apoptosis: a basic biological phenomenon with wide-ranging 1mplications in tissue kinetics. British Journal of Cancer, 26, 239-257.

[5] Galluzzi, L., Vitale, I., Abrams, J.M., Alnemri, E.S., Baehrecke, E.H., Blagosklonny, M.V., Dawson, T.M., Dawson, V.L., El-Deiry, W.S., Fulda, S., Gottlieb, E., Green, D.R., Hengartner, M.O., Kepp, O., Knight, R.A., Kumar, S., Lipton, S.A., Lu, X., Madeo, F., Malorni, W., Mehlen, P., Nuñez, G., Peter, M.E., Piacentini, M., Rubinsztein, D.C., Shi, Y., Simon, H.U., Vandenabeele, P., White, E., Yuan, J., Zhivotovsky, B., Melino, G., Kroemer, G., (2012). Molecular definitions of cell death subroutines: recommendations of the Nomenclature Committee on Cell Death. Cell Death and Differantiation, 19(1), 107120.

[6] Green D.R., Galluzzi L., Kroemer G., (2011). Mitochondria and the autophagy-inflammation-cell death axis in organismal aging. Science, 333(6046), 1109-1112.

[7] Hengartner, M.O., (2000). The biochemistry of apoptosis. Nature, 407, 770-776.

[8] Elmore, S., (2007). Apoptosis: a review of programmed cell death. Toxicologic Pathology, 35(4), 495-516.

[9] Jacobsen, M.D., Weil, M., Raff, M.C., (1997). Programmed cell death in animal development. Cell, 88, 347-354.

[10] Earnshaw, W.C., Martins, L.M., Kaufmann, S.H., (1999). Mammalian caspases: Structure, activation, substrates and functions during apoptosis. Annual Review of Biochemistry, $68,383-424$.

[11] Denault, J.B., Salvesen, G.S., (2002). Caspases: Keys in the ignition of cell death. Chemical Reviews, 102, 4489-4499.

[12] Öz-Arslan, D., Korkmaz, G., Gözüaçık, D., (2009). Otofaji: Bir hücresel stres yanıtı ve ölüm mekanizması. Acıbadem Üniversitesi Sağllk Bilimleri Dergisi, 2, 184-194.

[13] Ouyang, W., Liao, W., Luo, C.T., Yin, N., Huse, M., Kim, M.V., Peng, M., Chan, P., Ma, Q., Mo, Y., Meijer, D., Zhao, K., Rudensky, A.Y., Atwal, G., Zhang, M.Q., Li, M.O., (2012). Novel foxo1-dependent transcriptional programs control T(reg) cell function. Nature, 22, 491(7425), 554-559.

[14] Michaeli, S., Galili, G., Genschik, P., Fernie, A.R., Avin-Wittenberg, T., (2016). Autophagy in plants: What's new on the menu. Trends in Plant Science, 21(2), 134-144.

[15] Leist, M., Jaattela, M., (2001). Four deaths and a funeral: From caspases to alternative mechanisms. Nature Reviews Molecular Cell Biology, 2(8), 589-98.

[16] Wu, J.J, Poon, K.Y., Channual, J.C., Shen, A.Y., (2012). Association between tumor necrosis factor inhibitor therapy and myocardial infarction risk in patients with psoriasis. Archives of Dermatology., 148(11), 1244-50.

[17] McCall, K., (2010). Genetic control of necrosis - another type of programmed cell death. Current Opinion in Cell Biology, 22(6), 882-888.
[18] Galluzzi, L., Vitale, I., Kroemer, G., (2011). Cell death signaling and anticancer therapy. Frontiers in Oncology, 1, 1-18.

[19] Woltering, E.J., Van der Bent, A., Hoeberichts, F.A., (2002). Do plant caspases exist? Plant Physiology, 130, 1764-1769.

[20] Danon, A., Rotari, V.I., Gordon A., Mailhac N., Gallois, P., (2004). Ultraviolet-C overexposure induces programmed cell death in Arabidopsis which is mediated by caspase-like activities and which can be suppressed by caspase inhibitors, p35 and defender against apoptotic death. Journal of Biological Chemistry, 279, 779-787.

[21] van Doorn,W.G., Beers, E.P., Dangl, J.L., Franklin-Tong, V.E., Gallois, P., Hara-Nishimura, I., Jones, A.M., Kawai-Yamada, M., Lam, E., Mundy, J., Mur, L.A., Petersen, M., Smertenko, A., Taliansky, M., Van Breusegem, F., Wolpert, T., Woltering, E., Zhivotovsky, B., Bozhkov, P.V., (2011). Morphological classification of plant cell deaths. Cell Death and Differantiation, 18(8), 1241-1246.

[22] Gunawardena, A.H., (2008). Programmed cell death and tissue remodelling in plants. Journal of Experimental Botany, 59(3), 445-51.

[23] Huang, S., Mira, M.M., Stasolla, C., (2016). Dying with style: Death decision in plant embryogenesis. In: In vitro embryogenesis in higher plants, M.A. Germaná, M. Lambardi, (eds), Springer, NewYork, USA. s. 101-115.

[24] Munné-Bosch, S., (2016). Flower senescence ant other programmed cell death processes in plants: Atribute to the late Wouter G. Van Door. Journal of Experimental Botany, 67(20), 5885-5886.

[25] Hülskamp, M., (2004). Plant trichomes: A model for cell differentiation. Nature Reviews Molecular Cell Biology, 5(6), 471-480.

[26] Vardar, F., Ünal, M., (2012). Ultrastructural aspects and programmed cell death in the tapetal cells of Lathyrus undulatus Boiss. Acta Biologica Hungarica, 63(1), 52-66.

[27] Çetinbaş-Genç A., (2016). Türkiye endemiği olan Crataegus tanacetifolia (Lam.) Pers. (Alıç)' in üreme biyolojisinin analizi. Doktora Tezi, Marmara Üniversitesi, Türkiye, s. 106107.

[28] Wu, H.M., Cheung, A.Y., (2000). Programmed cell death in plant reproduction. Development, 44, 267-281.

[29] Wei, C.X., Lan, S.Y., Xu, Z.X., (2002). Ultrastructural features of nucleus degradation during programmed cell death of starchy endosperm cells in rice. Acta Botanica Sinica, 44, 1396-1402.

[30] Van Hautegem, T., Waters, A.J., Goodrich, J., Nowack, M.K., (2015). Only in dying, life: programmed cell death during plant development. Trends in Plant Science, 20: 102-113.

[31] Vardar, F., Ünal, M., (2011). Development and programmed cell death in the filament cells of Lathyrus undulatus Boiss. Caryologia, 64(2), 164-172.

[32] Van Durme, M., Nowack, M.K., (2016). Mechanisms of developmentally controlled cell death in plants. Current Opinion in Plant Biology, 29, 29-37. 
[33] Drew, M.C., He, C.J., Morgan, P.W., (2000). Programmed cell death and aerenchyma formation in root. Trends in Plant Science, 5, 123-127.

[34] Jones, A.M., Dangl, J.L., (1996). Logjam at the styx: Programmed cell death in plants. Trends in Plant Science, 1, 13601385.

[35] Dietrich, R.A., Delaney, T.P., Uknes, S.J., Ward, E.R., Ryals, J.A., Dangl, J.L., (1994). Arabidopsis mutants simulating disease resistance response. Cell, 77, 565-577.

[36] Smirnoff, N., (1993). The role of active oxygen in the response of plants to water deficit and desiccation. New Phytologist, 125, 27-58.

[37] Sgherry, C.L.M., Pinzino, C., Navari-Izzo, F., (1996). Sunflower seedlings subjected to increasing water stress by water deficit: Changes in $\mathrm{O}_{2}$-production related to the composition of thylakoid membranes. Physiologia Plantarum, 96, 446-452.

[38] Büyük, İ., Soydam-Aydın, S., Aras, S., (2012). Bitkilerin stres koşullarına verdiği moleküler cevaplar. Türk Hijyen ve Deneysel Biyoloji Dergisi, 69, 2, 97-100.

[39] Van Breusegem, F., Dat, J. F., (2006). Reactive oxygen species in plant cell death. Plant Physiology, 141, 384-390.

[40] Levitt, J., (1972). Responses of plants to environmental stresses. New York, London.

[41] Flora, S. J., (2007). Role of free radicals and antioxidants in health and disease. Cellular and Molecular Biology, 53, 1-2.

[42] Gill, S.S., Tuteja, N., (2010). Reactive oxygen species and antioxidant machinery in abiotic stres tolerance in crop plants. Plant Physiology and Biochemistry, 48, 909-930.

[43] Gechev, T. S., Van Breusegem, F., Stone, J. M., Denev, I., Laloi, C., (2006). Reactive oxygen species as signals that modulate plant stress responses and programmed cell death. Bioessays, 28, 1091-1101.

[44] Noctor, G., Foyer, C. H., (1998). Ascorbate and glutathione: keeping active oxygen under control. Annual Review of Plant Biology, 49, 249-279.

[45] Zaefyzadeh, M., Quliyev, R., Babayeva, S., Abbasov, M., (2009). The effect of the interaction between genotypes and drought stress on the superoxide dismutase and chlorophyll content in durum wheat landraces. Turkish Journal of Biology, 33, 1-7.

[46] Chen, Q., Zhang, M., Shen, S., (2010). Effect of salt on malondialdehyde and antioxidant enzymes in seedling roots of Jerusalem artichoke (Helianthus tuberosus L.). Acta Physiologiae Plantarum, 33, 273-278.

[47] Apel, K., Hirt, H., (2004).Reactive oxygen species: Metabolism, oxidative stress, and signal transduction. Annual Review of Plant Biology, 55, 373-399.

[48] Sharma, P., Jha, A.B., Dubey, R.S., Pessarakli, M., (2012). Reactive oxygen species, oxidative damage, and antioxidative defense mechanism in plants under stressful conditions. Journal of Botany, Article ID 217037, 26.
[49] Yi, J., Moon, S., Lee, Y.S., Zhu, L., Liang, W., Zhang, D., Jung, K.H., An, G., (2016). Defective tapetum cell death 1 (DTC1) regulates ROS levels by binding to metallothionein during tapetum degeneration. Plant Physiology, 170, 1611-1623.

[50] Xie, H.T., Wan, Z.Y., Li, S., Zhang, Y., (2014). Spatiotemporal production of reactive oxygen species by NADPH oxidase is critical for tapetal programmed cell death and pollen development in Arabidopsis. Plant Cell, 26, 2007-2023.

[51] Wilkins, K.A., Poulter, N.S., Franklin-Tong, V.E., (2014). Taking one for the team: Self-recognition and cell suicide in pollen. Journal of Experimental Botany, 65, 1331-1342.

[52] Duan, Q., Kita, D., Johnson, E.A., Aggarwal, M., Gates, L., Wu, H.M. Cheung, A.Y., (2014). Reactive oxygen species mediate pollen tube rupture to release sperm for fertilization in Arabidopsis. Nature Communications, 5, 3129.

[53] Yalçın, G., Vardar, F., (2016). The alleviating effects of salicylic acid application against aluminium toxicity in barley (Hordeum vulgare L.) roots. Biologia, 71(12), 1338-1344.

[54] Hatsugai, N., Yamada, K., Goto-Yamada, S., Hara-Nishimura, I., (2015). Vaculolar processing enzyme in plant programmed cell death. Frontiers in Plant Science, 6, 234.

[55] Grudkowska, M., Zagdańska, B., (2004). Multifunctional role of plant cysteine proteinases. Acta Biochimica Polonica, 51, 609-624.

[56] Coffeen, W.C., Wolpert, T.J., (2004). Purification and characterization of serine proteases that exhibit caspase-like activity and are associated with programmed cell death in Avena sativa. Plant Cell, 16, 857-873.

[57] Del Pozo, O., Lam, E., (1998). Caspases and programmed cell death in the hypersensitive response of plants to pathogens. Current Biology, 8(20), 1129-1132.

[58] Uren, A.G., O'Rourke, K., Aravind, L., Pisabarro, M.T., Seshagiri, S., Koonin, E.V., Dixit, V.M., (2000). Identification of paracaspases and metacaspases: Two ancient families of caspase-like proteins, one of which plays a key role in MALT Lymphoma. Molecular Cell, 6, 961-967.

[59] Suarez, M.F., Filonova, L.H., Smertenko, E.I., Clapham, D.H., von Arnold, S., Zhivotovsky, B., Bozhkov, P.V., (2004). Metacaspase dependent programmed cell death is essential for plant embryogenesis. Current Biology, 14, 339-340.

[60] Huysmans, M., Lema, S., Coll, N.S., Nowack, M.K., (2017). Dying two deaths-Programmed cell death regulation in development and disease. Current Opinion in Plant Science, 35, 37-44.

[61] Hatsugai, N., Kuroyanagi, M., Yamada, K., Meshi, T., Tsuda, S., Kondo, M., (2004). A plant vacuolar protease, VPE, mediates virus-induced hypersensitive cell eath. Science, 305, 855-858.

[62] Ayturk, O., Vardar, F., (2014). Aluminum-induced caspase-like activities in some Gramineae species. Advances in Food Sciences, 37(2), 71-75.

[63] Yanik, F., Ayturk, O., Vardar, F., (2017). Programmed cell death evidence in wheat (Triticum aestivum L.) roots induced 
by aluminum oxide $\left(\mathrm{Al}_{2} \mathrm{O}_{3}\right)$ nanoparticles. Caryologia, 70(2), 112-119.

[64] Tsiatsiani, L., van Breusegem, F., Gallois, P., Zavialov, A., Lam, E., Bozhkov, P.V., (2011). Metacaspases. Cell Death and Differentiation, 18, 1279-1288.

[65] Güleş, Ö., Eren, Ü., (2008). Apoptozun belirlenmesinde kullanılan yöntemler. Yüzüncü Yıl Üniversitesi Veteriner Fakültesi Dergisi, 2, 73-78.

[66] Fidan, A.F., (2005) DNA Hasar tespitinde tek hücre jel elektroforezi. Afyon Kocatepe Üniversitesi Fen Ve Mühendislik Bilimleri Dergisi, 8(1), 41-52.

[67] Vardar, F., Çabuk, E., Aytürk, Ö., Aydın, Y., (2016). Determination of aluminum induced programmed cell death characterized byDNA fragmentation in Gramineae species. Caryologia 69, 111-115

[68] Yanık, F., Vardar, F., (2015). Toxic effects of aluminum oxide $\mathrm{Al}_{2} \mathrm{O}_{3}$ nanoparticleson root growth and development in Triticum aestivum. Water Air and Soil Pollution, 226, 296-309.

[69] Vardar, F., Akgül, N., Aytürk, Ö., Aydın, Y., (2015). Assessment of aluminum induced genotoxicity with comet assay in wheat rye and triticale roots. Fresenius Environmental Bulletin, 24, 3352-3358.

[70] Panda, S.K., Yamamoto Y., Kondo H., Matsumoto H., (2008). Mitochondrial alterations related to programmed cell death in tobacco cells under aluminum stress. Comptes Rendus Biologies, 331, 597-610. 